\title{
Triterpenoids from the leaves of Dendropanax morbifera Léveille and its cytotoxic activity toward breast MCF-7 and lung A549 cancer cells
}

\author{
Soyi Park ${ }^{1}$, Kwontack Hwang ${ }^{2}$, Ju-ryun $\mathrm{Na}^{1}$, Kihoon Lee ${ }^{1}$, Eui-seon Jeong ${ }^{1}$, \\ Sunoh $\mathrm{Kim}^{1 *}$ \\ ${ }^{1}$ B\&Tech Co., Ltd., R\&D Center, Gwangju 61239, Korea \\ ${ }^{2}$ Department of Food and Nutrition, Nambu University, Gwangju 62271, Korea
}

\begin{abstract}
Dendropanax morbifera Léveille (Araliaceae) is an endemic species growing in the south-westem part of South Korea and has been used in folk medicine and health functional food. Several studies have indicated that extract of $D$. morbifera (DP) has cytotoxic activities on a number of human cancers, such as, breast cancer, lung cancer, hepatoma, and chorioepithelioma. Recently, polyacetylene and triterpene compounds have been isolated from the DP and showed to have anti-complement activity. $\beta$-Amyrin, $\alpha$-amyrin, dendropanoxide, and $\beta$-sitosterol are isolated from DP. However, its biological activities in cancer have not yet been clearly elucidated. In this study, we evaluated the anti-cancer activity of isolated triterpenoids from the DP leaves by measuring the levels of cytotoxicity against MCF-7 human breast cancer and A549 human lung cancer cells. Six triterpenoids were isolated from the n-hexane fraction of DP leaves along with the known compounds. $\beta$-amyrin (1), a-amyrin (2), olean-12-en-3,24 $\beta$-diol (3), dendropanoxide (4), $\beta$-sitosterol (5), and stigmasterol (6). Compound 3 and 6 were isolated from DP for the first time. Cytotoxic activities of six compounds were evaluated against two human cancer cell lines by using the MTT in vitro assay. Among them, five compounds (1, 2, 4, 5, and 6) showed moderate cytotoxic activities toward the tested cell lines, and were safe to normal cells. Westem blot analysis showed a decreased expression of anti-apoptotic protein Bcl-2 and increased levels of pro-apoptotic protein Bax in MCF-7 and A549 cells treated by $\beta$-amyrin and a-amyrin. Flow cytometry analysis confirmed that five compounds $(1,2,4,5$, and 6$)$ treatment increased populations of sub-G1 (apoptosis) phase. The results of the present study revealed that triterpenoids from DP have the potential for further development as anticancer agents.
\end{abstract}

Key words : Dendropanax morbifera Léveille, anticancer, triterpenoid, cytotoxic activity, $\beta$-amyrin, $a$-amyrin

\section{Introduction}

Cancer causes serious problem which leads to morbidity and mortality and creates worldwide problem in public health Effective anti-cancer compounds are not well known. Plant based compounds are better curative compounds than synthetic compounds. However, the majority of cancer cases are still treated by chemotherapy, especially for advanced stage cancer (1). The major problems of chemotherapeutic

*Corresponding author. E-mail : sunoh@korea.ac.kr Phone : 82-62-528-2201, Fax : 82-62-528-2202

Received 6 July 2018; Revised 21 July 2018; Accepted 21 July 2018.

Copyright (c) The Korean Society of Food Preservation. All rights reserved. treatment in cancer are non-specific cytotoxicity and drug resistance (2). Therefore, investigations to discover new and effective anti-cancer agents have become a serious issue $(1,3)$. With this aim, many attentions have been paid to natural compounds in plants, marine organism and microorganisms. Regarding the low side effects of plants and other natural compounds, scientists are interested in working on them to find new medications.

Plant-derived products, known as natural therapies, have been used for thousands of years in cancer treatment with a very low number of side effects (4). Furthermore, it has been reported that plant constituents are able to directly inhibit the proliferation of cancer cells. The ability of medicinal plants to show a broad range of activity has been attributed to their ability to affect multiple targets. However, the 
mechanism of action is still largely unknown (5). A number of anti-cancer drugs have been shown to induce apoptosis in susceptible cancer cells (6-9). Apoptosis is a genetically controlled response by which cells commit suicide and has become a major focus in the study of cancer biology and tumor progression (10-12). Despite tremendous efforts to explore the components involved in the process of apoptotic cell death, the molecular linkages of these components and their mechanisms of action are still largely unknown.

Member of Bcl-2 family have been shown to play an important regulatory role in apoptosis, either as activators (e.g. Bax, Bid, Bim, or Bak) or inhibitors (e.g. Bcl-2, Bcl-w, or Bcl-X ${ }_{\mathrm{L}}$ (13). Among the Bcl-2 family members, Bcl-2 itself is particularly cell death triggered by multiple stimuli in a variety of cell types $(10,11)$. In addition, Bcl-2 has been shown to act upstream of apoptotic proteases such as caspase-3, preventing their proteolytic activation and thereby interfering with signaling pathways that lead to apoptosis $(11,14,15)$.

Dendropanax morbifera Léveille (Araliaceae) is an endemic species growing in the south-western part of South Korea and has been used in folk medicine as a health functional food for the treatment of headache, infectious diseases, and skin diseases. However, the underlying mechanisms for the varying activities observed with $D$. morbifera (DP) and its components are largely unclear. Several studies have indicated that extract of DP has cytotoxic activities on a number of human cancers, such as, breast cancer, lung cancer, hepatoma, and chorioepithelioma (16-21). Active ingredients such as rutin, polyacetylenes, or oleifoliosides (triterpenoids) purified from DP have been reported. Rutin, a flavonoid, protects against thromboembolism and neuronal injury $(22,23)$. Petylenes ((3S)-falcarinol, (3S,8S)-falcarindiol, and (3S)-diynene) were reported to inhibit complement activity (24). Oleifoliosides attenuate macrophage-mediated inflammation and show anticancer effect through inducing cell death (19,20). Recently, a new polyacetylens and triterpene oxide compounds were isolated from the DP by conventional chromatographic techniques and showed to have cytotoxic activities (24-28). In in vitro, a cycloartane-type glycoside, oleifolioside A, inhibited the metastasis of human cervical carcinoma (20). The dendropanoxide induced autophagy through ERK1/2 activation in human osteosarcoma cells and autophagy inhibition enhanced dendropanoxide-induced apoptosis (18). In addition, (9Z, 16S)-16-hydroxy-9,17octadecadiene-12,14-diynoic acid was reported to anti- complement activity against the classical pathway of the complement system (24). However, the previous studies were focused on the crude extract of DP and limited phytochemical tests, and none on its bioactive compounds.

More recently, we have also isolated a new compound, 1-tetradecanol, a straight-chain saturated fatty alcohol, from DP, which has skin whitening and moisturizing effects (29), potential preventive or therapeutic agent for Helicobacter pylori induced gastric inflammation (30), and a potent $\mathrm{T}$ cell growth factor (31). However, the inhibitory effects of single compounds of DP on cancer cells and its underlying molecular mechanisms have been studied in very few. Therefore, we have attempted to elucidate the possible biological mechanisms controlling the anticancer activity of DP.

In this study, two new triterpenoids and four know triterpenoids were isolated from the n-hexane fraction of DP. Based on chemical and spectral analysis, the structures of the six triterpenoids were determined to be $\beta$-amyrin (1), a-amyrin (2), olean-12-en-3,24 $\beta$-diol (3), dendropanoxide (4), $\beta$-sitosterol (5), and stigmasterol (6). $\beta$-Amyrin and $\beta$ -sitosterol from the Prunus africana are moderately cytotoxic against colorectal carcinoma, Caco-2 cells, while low cytotoxicity is observed on hepatocellular carcinoma, HepG2 cells (32). Stigmasterol from the Azadirachta indica has been chemopreventive effect on 7,12-dimethylbenz[a]anthracene (DMBA)-induced skin cancer (33). Dendropanoxide from the DP has anti-cancer activities in MG-63 human osteosarcoma cells (18). Given the potential of triterpmoids and the benefits of DP, there should be further investigation of this bioactive compounds derived from DP toward effective and safe anticancer agent. We evaluated the cytotoxicity of isolated six compounds 1-6 from DP against two cancer cell lines A-549 human lung cancer and MCF-7 human breast cancer cells. Furthermore, the mechanisms of triterpenoids anti-cancer activities were determined. The result of this study are expected to contribute and the development of DP as effective therapeutics against breast and lung cancer.

\section{Materials and methods}

\section{General experimental procedures}

Optical rotations were determined on a Jasco DIP-370 automatic polarimeter (Jasco, Kyoto, Japan). The fourier transform infrared spectrophotometer (FT-IR) spectra were obtained from a Jasco Reports-100 infrared spectrometer 
using $\mathrm{KBr}$ plates (Jasco). The nuclear magnetic resonance (NMR) spectra were recorded on a Agilents $400 \mathrm{MHz}$ (Agilent Technologies ${ }^{\circledR}$, Palo Alto, CA, USA) for ${ }^{1} \mathrm{H}-\mathrm{NMR}$ (400 $\mathrm{MHz}),{ }^{13} \mathrm{C}-(100 \mathrm{MHz}) 1 \mathrm{D}-\mathrm{NMR}$, heteronuclear multiple-bond correlation (HMBC), heteronuclear single- quantum correlation spectroscopy (HSQC) 2D-NMR. Column chromatography was carried out silica gel (Kieselgel $60 \mathrm{~F}_{254}$, 70-230 mesh, Merck, Darmstadt, Germany), Lichroprep RP-18 (40-63 $\mu \mathrm{M}$, Merck), and TLC was performed on a pre-coated silica gel $60 \mathrm{~F}_{254}(0.25 \mathrm{~mm}$, Merck). Spot were detected under UV light or after spraying with $10 \% \mathrm{H}_{2} \mathrm{SO}_{4}$ reagent, followed by heating.

\section{Extraction and isolation}

The dried leaves of DP were collected from Jangheung, Jeollanamdo, Korea, in October 2017 and authenticated by Dr. Kim at the B\&Tech Co., Ltd., R\&D Center, Gwangju, Korea. Extracts were obtained from leaves $(1.3 \mathrm{~kg})$ using (v/w) of $100 \%$ methanol $(\mathrm{MeOH})$ at $60^{\circ} \mathrm{C}$ for $4 \mathrm{~h}$. Extracted solutions were filtered and concentrated using an evaporator under vacuum and $125 \mathrm{~g}$ of crude extract was obtained. The residue $(90 \mathrm{~g})$ was dissolved in water $(1,000 \mathrm{~mL})$ and partitioned with solvents to give n-hexane $(35.2 \mathrm{~g}), \mathrm{CHCl}_{3}(8.1$ g), EtOAc (810 mg), n-BuOH (17.44 g) and $\mathrm{H}_{2} \mathrm{O}$ (30.5 g) soluble portions. The $\mathrm{n}$-hexane fraction $(6 \mathrm{~g})$ was separated over a silica gel column with hexane-acetone (100:1-1:1) solvent system as the eluent to give ten fractions (H1-H10). Fraction H-1 (146.0 mg) re-chromatographed on a silica gel column with hexane-acetone (100:1-80:1) as the eluent to give the known compounds 1 (10.0 mg), compounds 3 (3.0 $\mathrm{mg}$ ). Fraction $\mathrm{H}-4$ (80.7 $\mathrm{mg}$ ) was purified by column chromatography over silica gel using a hexane:acetone gradient (100:1-1:1) and further separated with silica gel column chromatography to afford compound 2. Fraction H-6 (98.6 mg) was purified by chromatography over silica gel using a hexane-acetone gradient (100:1-1:1) and further purified with a silica gel column by hexane-acetone (10:1) as the eluent to give compounds $5,6(10 \mathrm{mg}$ and $4.3 \mathrm{mg}$ ). Fraction H-7 (654 mg) was purified by column chromatography over silica gel using a hexane-acetone gradient (100:1-1:1) and further separated with LiChroprep RP-18 column chromatography to afford compound 4 .

\section{Cell cultures}

Two human cancer cell lines and normal African green monkey kidney cells, Vero, were used. The A-549 (Human lung cancer) and MCF-7 (human breast cancer) cell lines were obtained from the Korea Cell Line Bank (KCLB, Seoul, Korea) and Vero cell line was ATCC (CCL-81, Manassas, VA, USA) and were grow in Dulbecco's Modified Eagle medium/Nutrient Mixture F-12 (DMEM/F-12, Gibco; Thermo Fisher Scientific Inc., Waltham, MA, USA) supplemented with $10 \%$ fetal bovine serum (FBS, Gibco; Thermo Fisher Scientific Inc.) and penicillin/streptomycin $\left(100 \mathrm{U} / \mathrm{mL}\right.$ and $100 \mathrm{\mu g} / \mathrm{mL}$, respectively) at $37^{\circ} \mathrm{C}$ in a humidified $5 \% \mathrm{CO}_{2}$ atmosphere. The experiments were done at $70-80 \%$ confluence. Upon reaching confluence, cells were detached using $0.25 \%$ trypsin-ethylene diamine tetra acetic acid (EDTA) solution.

\section{Cell viability (MTT) assay}

The inhibitory effects of compounds (1-6) on the growth of human cancer cells were determined by measuring metabolic activity using a 3-(4,5-dimethylthiazol-2-yl)2,5-diphenyl-terazolium bromide (MTT) assay according to Denizot et al. (34). Briefly, the collected cells were seeded into a 24-well culture plate (Nunc, Rochester, NY, USA) at a density of $4 \times 10^{5}$ cells per well and incubated for 24 h. Cells, replaced by FBS-free culture medium, were treated with $10,30,50,100$, and $200 \mu \mathrm{M}$ of with six compounds (1-6). After incubation, $0.1 \mathrm{mg}$ ( $50 \mu \mathrm{L}$ of a $2 \mathrm{mg} / \mathrm{mL}$ solution) MTT solution was added to each well and the cells were then incubated at $37^{\circ} \mathrm{C}$ for $4 \mathrm{~h}$. The plated were centrifuged at $1,000 \mathrm{rpm}$ for $10 \mathrm{~min}$ at room temperature and the media was then carefully aspirated. Dimethylsulfoxide (DMSO, 200 $\mu \mathrm{L}$ ) was then added to each well to dissolve the formazan crystals. The plates were read immediately at $570 \mathrm{~nm}$ on an ELISA plate reader (Epoch 2; BioTek Instruments, Inc., Winooski, VT, USA). All the experiments were performed three times and the mean absorbance values were calculated. The results are expressed as the percentage of inhibition that produced a reduction in the absorbance by the treatment of the compounds compared to the untreated controls. The sample concentration which inhibited $50 \%$ cell line $\left(\mathrm{IC}_{50}\right)$ was determined using relationship curve between the concentration of sample $(\mathrm{X})$ and the percentage inhibition (y).

\section{Western blot analysis}

The cells were plated at a density of $5 \times 10^{4}$ in six-well plates. They were allowed to grow at $37^{\circ} \mathrm{C}$ in a humidified $\mathrm{CO}_{2}$ incubator until they were $70-80 \%$ confluent. Then cells were treated with $\mathrm{IC}_{50}$ concentration of compounds for 24 h. Then cells were lysed in a buffer $(50 \mathrm{mM}$ Tris- $\mathrm{HCl}, \mathrm{pH}$ 
7.4 containing $150 \mathrm{mM} \mathrm{NaCl}, 1 \mathrm{mM}$ EGTA, $1 \mathrm{mM}$ EDTA, and $10 \%$ glycerol) that contained the protease inhibitors leupeptin $(10 \mu \mathrm{g} / \mathrm{mL})$ and phenyl methane sulfonyl fluoride (PMSF) ( $2 \mathrm{mM})$. The protein concentration was determined according to the method described by the Bio-Rad protein assay manual. Western blot was conducted to analyse the effects of compound (1-6) on the expressions of apoptosis regulators Bcl-2 and Bax in the MCF-7 and A-549 cells. Equal amounts of proteins (30 $\mathrm{\mu g} / \mathrm{lane})$ were diluted by loading dye and subjected to $10 \%$ sodium dodecyl sulphate-polyacrylamide gel electrophoresis (SDS-PAGE). The gel was then transferred to nitrocellulose membranes (Amersham, Berkshire, UK). The membranes were blocked with $5 \%$ skim milk in TBS containing $0.1 \%$ Tween-20, and then incubated at room temperature for $2 \mathrm{~h}$ with primary antibodies against Bax, Bcl-2, and $\beta$-actin (1:2,000, Santa Cruz Biotechnology, Santa Cruz, CA, USA) diluted according to the manufacturer's instructions. Following incubation with antibodies, the membranes were washed three times for 15 minutes in TBS-T and incubated for another $1 \mathrm{~h}$ with specific horseradish peroxidase (HRP)-conjugated goat anti-rabbit IgG (1:5,000, Santa Cruz Biotechnology, Santa Cruz, CA, USA) as the secondary antibody. Then the membranes were washed and developed with enhanced chemiluminescence (ECL) western blotting detection kit (Amersham, Arlington Heights, UK). The relative protein levels were determined using a ChemiDoc XRS+ System (Bio-Rad, Hercules, CA, USA) using Image Lab software version 5.2.1 (Bio-Rad).

\section{Flow cytometry analysis}

The cells were plated at a density of $5 \times 10^{4}$ in six-well plates. They were allowed to grow at $37^{\circ} \mathrm{C}$ in a humidified $\mathrm{CO}_{2}$ incubator until they were $70-80 \%$ confluent. Then, cells were treated with $\mathrm{IC}_{50}$ concentration of compounds for 24 h. Then cells were fixed by adding $2 \mathrm{~mL}$ of ice-cold $70 \%$ ethanol in a drop-wise manner while gently vortexing, after which they were stored at $-20^{\circ} \mathrm{C}$ until analysis. The fixed cells were rinsed with phosphate buffered saline and then incubated in $500 \mu \mathrm{L}$ propidium iodine (PI) solution $(10 \mathrm{mM}$ Tris, $\mathrm{pH} 8$, containing $1 \mathrm{mM} \mathrm{NaCl}, 0.1 \%$ Nonidet P-40, 0.7 $\mu \mathrm{g} / \mathrm{mL}$ RNase A, and $0.05 \mu \mathrm{g} / \mathrm{mL} \mathrm{PI}$ ) for $15 \mathrm{~min}$ at $37^{\circ} \mathrm{C}$. The analyses of cell apoptosis and cell cycle were subsequently analyzed using flow cytometry (FACSCalibur ${ }^{\mathrm{TM}}$, Beckton Dickinson, GmbH, Heidelberg, Germany) equipped with an argon ion laser. CellQuest Pro software was used to record and analyze the data from 10,000 nuclei.

\section{Statistical analysis}

Data were recorded as means \pm standard deviation (SD) and evaluated using Student's t-test or a one-way analysis of variance (ANOVA), followed by Duncan's Multiple Range test for comparison of significant differences between groups at $\mathrm{p}<0.05$.

\section{Results and discussion}

\section{Chemical properties of new triterpenoids}

Six compounds (1-6) were isolated from the methanol extract of DP (Fig. 1). Olean-12-en-3,24 $\beta$-diol (compound 3 ) and stigmasterol (compound 6) were isolated for the first time from DP. Compound 3 was obtained as colorless needle. Its identified by its FT-IR spectrum, with peaks at 3,600-3,100, 1,630, 1,038, 1,020, $810 \mathrm{~cm}^{-1}$. ${ }^{1} \mathrm{H}-\mathrm{NMR}$ peaks at 3.34 and 4.21 spm showed hydroxymethyl group, and 3.44 Sppm indicated

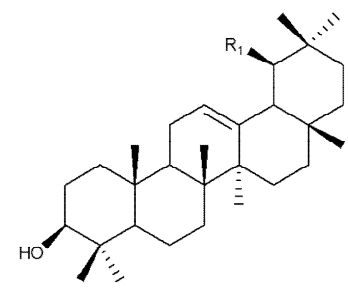

(A) $\beta$-Amyrin $\left(\mathbf{R}_{1}: \mathbf{H}\right)$ (B) a-Amyrin $\left(\mathrm{R}_{1}: \mathrm{CH}_{3}\right)$

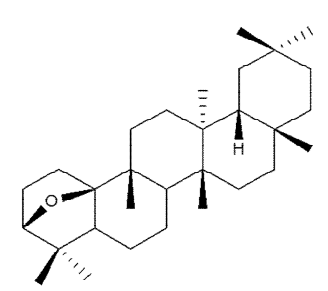

(C) Dendropanoxide

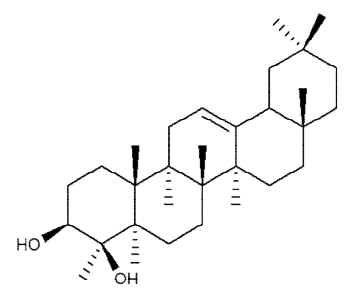

(D) Olean-12-en-3, 24 ß-diol

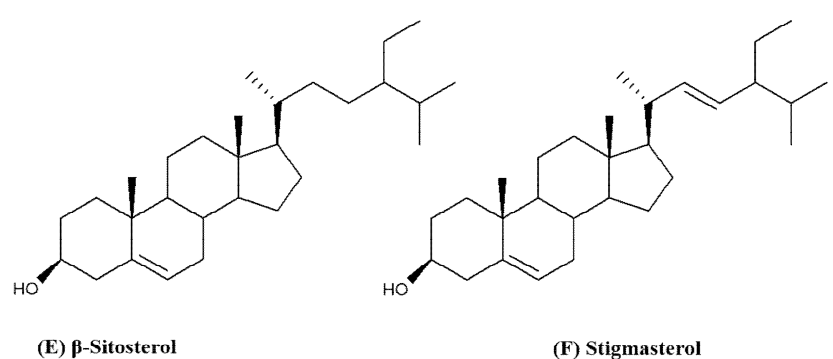

Fig. 1. Chemical structures of isolated compound from Dendropanax morbifera Léveille. 

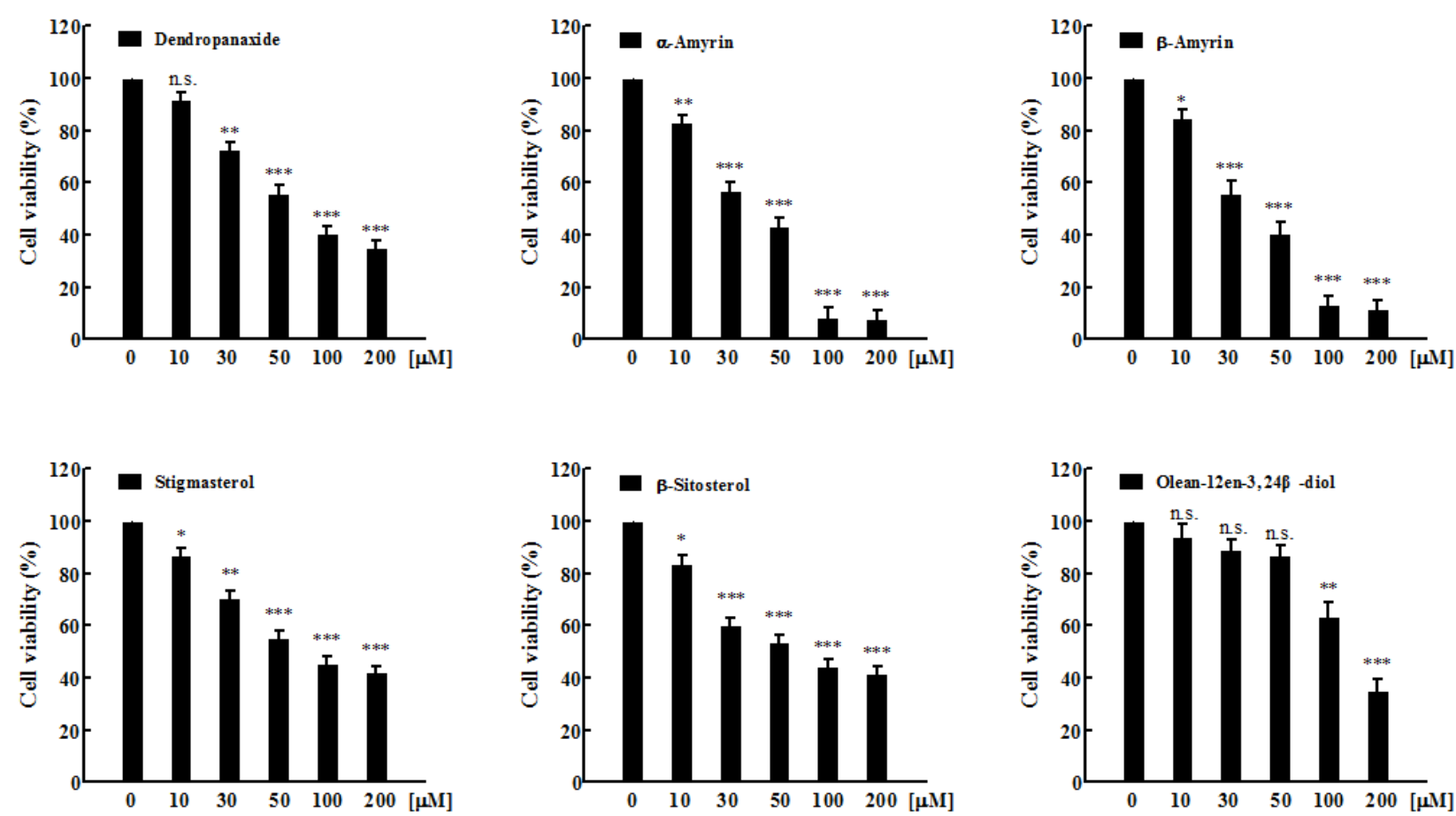

Fig. 2. Cytotoxic activities of isolated compound at various concentrations against human breast MCF-7 cancer cell lines.

Cell viability was determined by the MTT assay. Results represent six independent experiments in triplicate. Values from each treatment were expressed as a percent relative to the control $(100 \%)$. Each point represent the mean $\pm \mathrm{SD}$. ${ }^{\star} \mathrm{p}<0.05,{ }^{\star \star} \mathrm{p}<0.01,{ }^{\star \star \star} \mathrm{p}<0.001$.
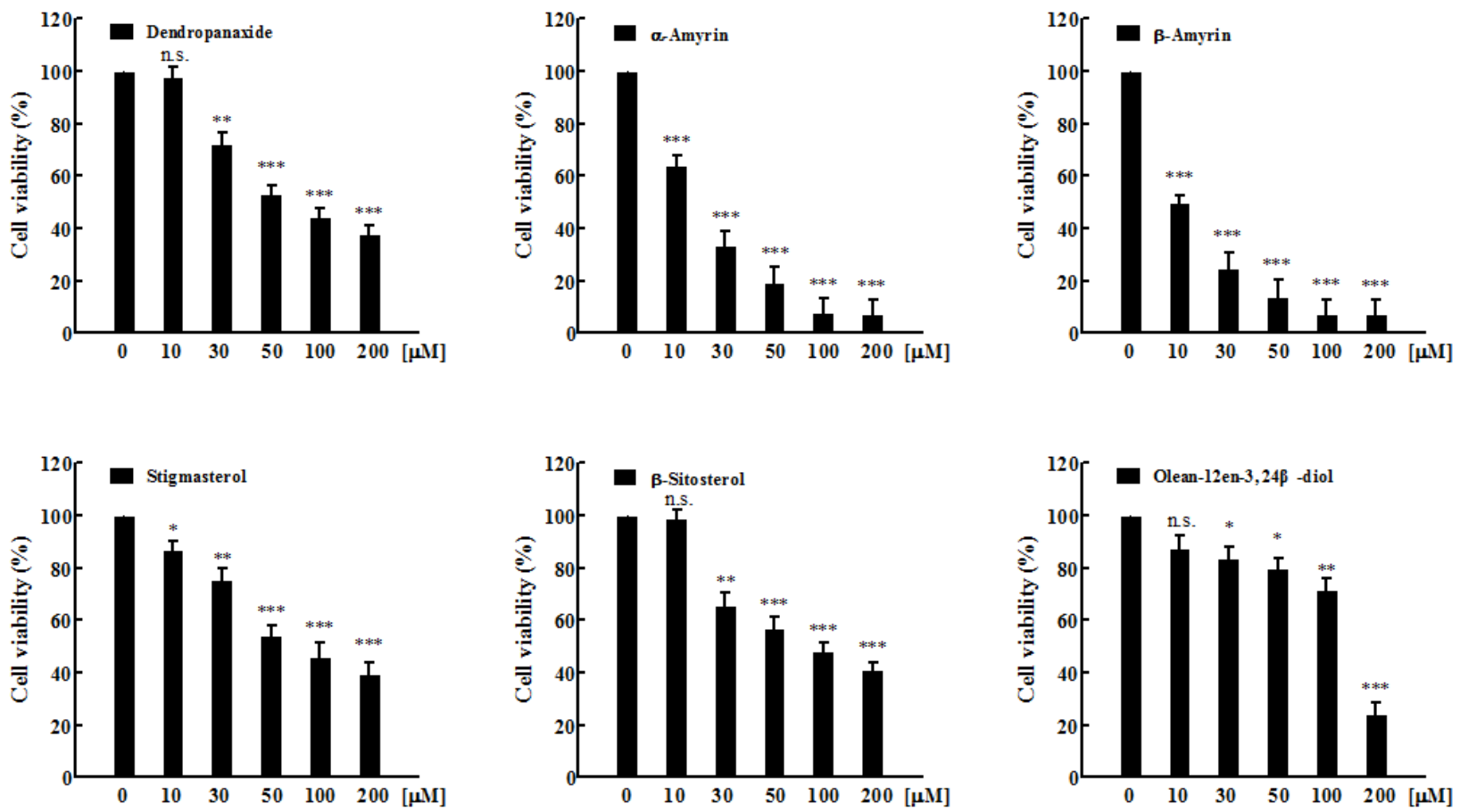

Fig. 3. Cytotoxic activities of isolated compound at various concentration against human lung A549 cancer cell lines.

Cell viability was determined by the MTT assay. Results represent six independent experiments in triplicate. Values from each treatment were expressed as a percent relative to the control $(100 \%)$. Each point represent the mean $\pm \mathrm{SD}$. ${ }^{\star} \mathrm{p}<0.05,{ }^{* \star} \mathrm{p}<0.01,{ }^{* \star *} \mathrm{p}<0.001$. 
methine group. EI-MS spectrum, the molecular ion peak was $m / z 442\left[\mathrm{M}^{+}\right]$. The FT-IR, ${ }^{1} \mathrm{H}-\mathrm{NMR}$, EI-MS data led to propose the molecular formula as $\mathrm{C}_{30} \mathrm{H}_{50} \mathrm{O}_{2}$, which closely resembles to Olean-12-en-3,24 $\beta$-diol, reported in the literature for the first time. Compound 6 was obtained as colourless crystals. Compound 6 identified by its FT-IR spectrum, with peaks at 3,494 $(\mathrm{OH}), 1,053$, and $1,020(\mathrm{OH})$ $\mathrm{cm}^{-1} .{ }^{1} \mathrm{H}-\mathrm{NMR}$ peaks at 1.59 and $1.61 \mathrm{\delta ppm}$ showed the presence of a cyclopentane. EI-MS spectrum, the molecular ion peak was $m / z 412\left[\mathrm{M}^{+}\right]$. The FT-IR, ${ }^{1} \mathrm{H}-\mathrm{NMR}$, EI-MS data led to propose the molecular formula as $\mathrm{C}_{29} \mathrm{H}_{48} \mathrm{O}$, which closely similar to those reported for stigmasterol in the published in the literature (33). The structures of the other triterpenoid compounds $1,2,4$, and 5 were also established based on their spectral data and by comparison with the literature (24). Concerning compounds 1-6, they were obtained from the leaves extract by the identical procedure described above.

B-amyrin (1) : White amorphous powder; $[a]_{D}+88.3^{\circ}$ $\left(\mathrm{c}=0.01, \mathrm{CHCl}_{3}\right)$; IR $(\mathrm{KBr}) V_{\max }: 3,300,2,950 \mathrm{~cm}^{-1}$; FAB-MS: $m / z 427[\mathrm{M}+\mathrm{H}]^{+}$

a-amyrin (2) : White amorphous powder; $[\mathrm{a}]_{\mathrm{D}}+92.0^{\circ}$ $\left(\mathrm{c}=0.005, \mathrm{CHCl}_{3}\right)$; IR(KBr) $V_{\max }: 3,300,2,950 \mathrm{~cm}^{-1}$; FAB-MS: $\mathrm{m} / \mathrm{z} 427[\mathrm{M}+\mathrm{H}]^{+}$

Olean-12-en-3,24 $\beta$-diol (3) : Colorless needles; $[\mathrm{a}]_{\mathrm{D}}+84.7^{\circ}$ $\left(\mathrm{c}=0.46, \mathrm{CHC}_{3}\right) ; \mathrm{IR}(\mathrm{KBr}) V_{\text {max }}: 3,600-3,100,1,630,1,038,1,020$, $810 \mathrm{~cm}^{-1}$; EI-MS: $\mathrm{m} / z \quad 442[\mathrm{M}]^{+}$

Dendropanoxide (4) : Colorless needles; $[a]_{D}+45.7^{\circ}$ (c=0.01, $\left.\mathrm{CHCl}_{3}\right) ; \mathrm{IR}(\mathrm{KBr}) \quad V_{\max }: 2,950 \mathrm{~cm}^{-1} ; \mathrm{FAB}-\mathrm{MS}: \mathrm{m} / \mathrm{z}$ $427[\mathrm{M}+\mathrm{H}]^{+}, 44[\mathrm{M}+\mathrm{Na}]^{+}$

$\beta$-sitosterol (5) : White amorphous powder; $[\mathrm{a}]_{\mathrm{D}}-40.7^{\circ}$ $\left(\mathrm{c}=0.05, \mathrm{CHCl}_{3}\right)$; IR(KBr) $V_{\max }: 3,400,2,930 \mathrm{~cm}^{-1}$; FAB-MS: $\mathrm{m} / \mathrm{z} 297[\mathrm{M}+\mathrm{H}]^{+}$

Stigmasterol (6) : Colourless crystals; $[\mathrm{a}]_{\mathrm{D}}-51^{\circ}(\mathrm{c}=0.1$, $\left.\mathrm{CHCl}_{3}\right)$; IR(KBr) $V_{\max }: 3,494(\mathrm{OH}), 1,053,1,020(\mathrm{OH}) \mathrm{cm}^{-1}$; EI-MS: $m / z 412[\mathrm{M}]^{+}$

Cytotoxic effects of triterpenoids on $\mathrm{MCF}-7$ and $\mathrm{A} 549$ cells

In vitro cytotoxic activity of six compounds at various concentration against MCF-7 and A549 cancer cell lines, and Vero normal cell lines were studied using MTT assay.
Anti-cancer activity of six compounds at various concentrations against MCF-7 cancer cell lines was represented in Figure 2. Under the experimental conditions used in $24 \mathrm{~h}$ treatment, all six compounds exhibited a marked growth inhibitory effect on MCF-7 cells in a dose-dependent manner. The result of all compounds (1-6) against MCF-7 cells with $\mathrm{IC}_{50}$ values were $33.60 \pm 5.46, \quad 32.70 \pm 3.60, \quad 168.0 \pm 2.84, \quad 78.27 \pm 2.20$, $71.49 \pm 3.56$, and $85.19 \pm 2.88 \mu \mathrm{M}$, respectively (Fig 4A). Compound 1 ( $\beta$-amyrin) and compound 2 (a-amyrin) exhibited the most potent cytotoxicity against MCF-7 cells. The other three compounds (stigmasterol, $\beta$-sitosterol, and dendropanoxide) showed moderate inhibition of cell growth at the same concentrations. Unlike the other compounds tested, compound 3 (Olean-12-en-3,24 $\beta$-diol) was inactive with an $\mathrm{IC}_{50}$ higher than $100 \mu \mathrm{M}$. These different sensitivities to six compounds-induced cytotoxicity were also evident from the results of the dose-course experiment shown in Figure 3. Nearly $90 \%$ of MCF-7 cells died within $24 \mathrm{~h}$ of treatment with $100 \mu \mathrm{M}$ of compound 1 and compound 2, also $24 \mathrm{~h}$ were required to reach similar level of cell death with A549 cells $(\mathrm{p}<0.001)$. At $24 \mathrm{~h}, \mathrm{IC}_{50}$ values of compound 1 and compound 2-treated A549 cells were 10.33 $\pm 7.4 \mu \mathrm{M}$ and $15.45 \pm 6.82 \mu \mathrm{M}$, respectively (Fig 4B). In addition, compound 4 (dendropanoxide; $\mathrm{IC}_{50}=83.71 \pm 1.74 \mu \mathrm{M}$ ), compound 5 ( $\beta$ -sitosterol; $\quad \mathrm{IC}_{50}=89.50 \pm 3.58 \mu \mathrm{M}$ ), and compound 6 (stigmasterol; $\mathrm{IC}_{50}=86.58 \pm 4.28 \mu \mathrm{M}$ ) exhibited a dose-dependent inhibitory effect on the growth of A549 cells. However, compound 3 (Olean-12-en-3,24 $\beta$-diol) was inactive with an $\mathrm{IC}_{50}$ higher than $100 \mu \mathrm{M}$. Moreover, A549 cells were more sensitive to the a-amyrin and $\beta$-amyrin-mediated cytotoxicity than MCF-7 cells (Fig. 4) Hence, further assay were carried out with each $\mathrm{IC}_{50}$ concentrations. To the best of our knowledge, this is the first time that the activity of these compounds is reported. Moreover, no cytotoxic effect was observed in non-cancer cells, Vero, by using six compounds (up to $200 \mu \mathrm{M}$ ) which demonstrated all six compounds treatments exhibit cytoselectivity towards normal Vero cells (data not shown). The Vero cells were used to evaluate the toxicity to normal cells to determine the safe level of administration of the sample as a medicine from some natural materials. Higher concentrations that inhibit above $50 \%$ of the normal cell growth should not be used for testing against cancer cells (35).

Expression of apoptotic related proteins in MCF-7 and A549 cells

The apoptotic process is controlled by several gene 

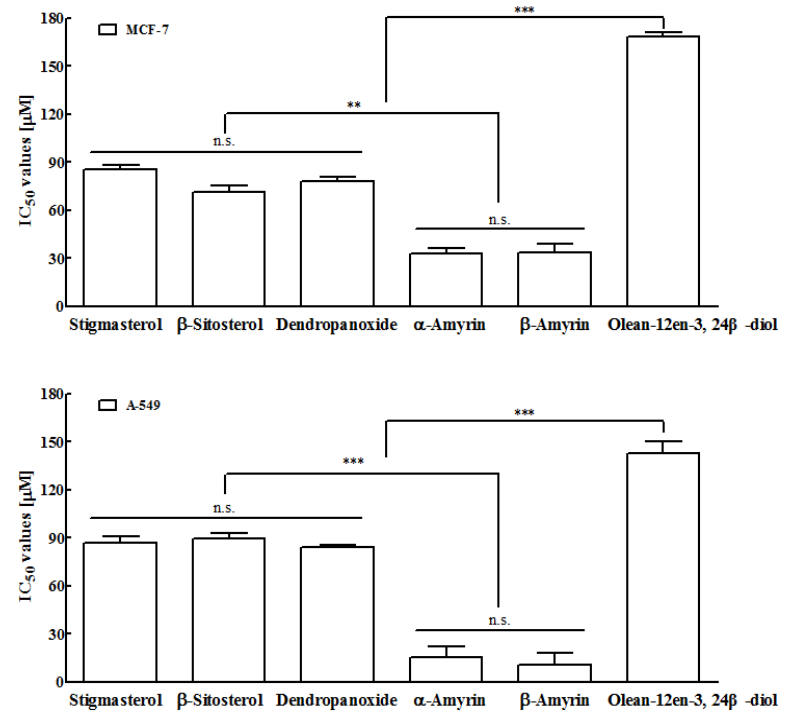

Fig. 4. $\mathrm{IC}_{50}(\mathrm{\mu M})$ values of isolated compound against selected cell lines. (A) human breast MCF-7 cancer cell lines and (B) human lung A549 cancer cell lines.

Data are expressed as $\mathrm{IC}_{50}$ in $\mu \mathrm{M}$ which is the concentration of compounds required to inhibit cell growth by $50 \%$. Data are presented as mean $\pm \mathrm{SD}$ of triplicate measurements. ${ }^{*} \mathrm{p}<0.05,{ }^{* *} \mathrm{p}<0.01,{ }^{* \star *} \mathrm{p}<0.001$.

(A)

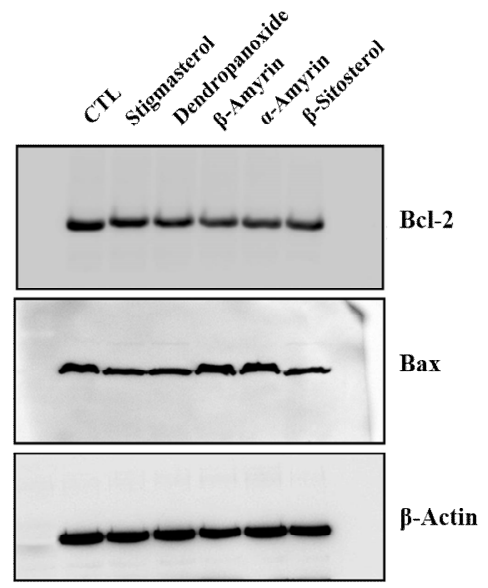

(B)

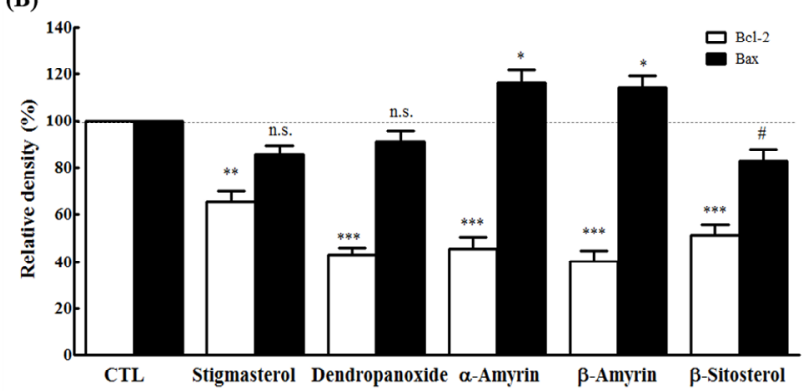

Fig. 5. Western blot analysis of Bcl-2 and Bax protein levels exposed to compounds. (A) MCF-7 cells were treated with $\mathrm{IC}_{50}$ concentrations of compounds for $24 \mathrm{~h}$.

A typical result out of three independent experiments is shown Relative changes in $\mathrm{Bcl}-2$ and Bax protein bands were measured using densitometric analysis. ${ }^{{ }^{*}} \mathrm{p}<0.05$, ${ }_{* *} \mathrm{p}<0.01,{ }^{* * *} \mathrm{p}<0.001$. products. There are group of genes involved in the regulation of the apoptosis which includes Bcl-2 and Bax (36). Bcl-2 is an anti-apoptotic gene and protects cells against the apoptosis in a variety of experimental systems (37). Various types of stimuli and anti-cancer drugs suppress the expression of $\mathrm{Bcl}-2$ to promote apoptosis (36). Bax exhibits their apoptotic effect by binding to Bcl-2 protein family and also prevents the activation of cytochrome c (37). To understand the mechanism of action of five active compounds (1,2, 4, 5, and 6), we studied the involvement of Bcl-2 and Bax in compounds mediated apoptosis and the effects in MCF-7 and A549 cells. Western blotting was performed to determine their expression level in cells treated with $\mathrm{IC}_{50}$ concentrations of compound 1, 2, 4, 5, and 6. As demonstrated in Fig. 5, all compounds caused Bcl-2 protein levels were markedly decreased in MCF-7 cells. On the other hand, only two compounds ( $a$-amyrin and $\beta$-amyrin) resulted in significantly increased expression of Bax. As demonstrated in Fig. 6, Bcl-2 protein levels were markedly decreased by all compounds in A549 cells. However, the treatment of three compounds

(A)

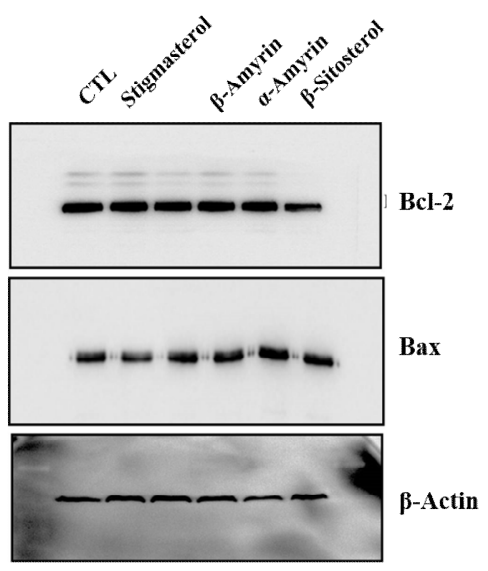

(B)

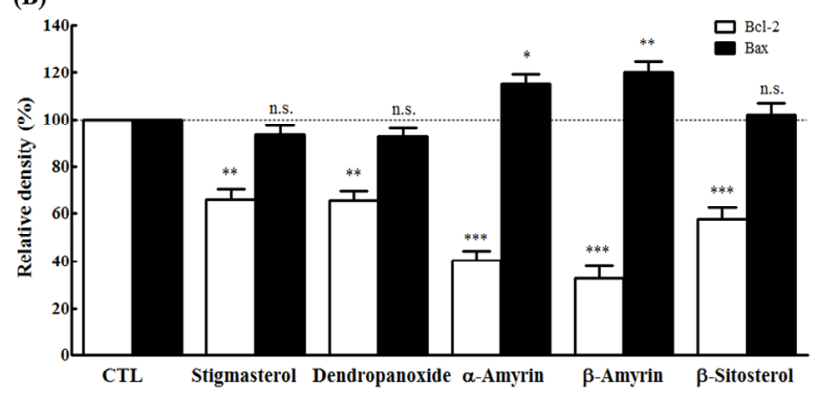

Fig. 6. Western blot analysis of Bcl-2 and Bax protein levels exposed to compounds. (A) A549 cells were treated with $\mathrm{IC}_{50}$ concentrations of compounds for $24 \mathrm{~h}$.

A typical result out of three independent experiments is shown. Relative changes in $\mathrm{Bcl}-2$ and Bax protein bands were measured using densitometric analysis. ${ }^{*} \mathrm{p}<0.05$, ${ }^{* *} \mathrm{p}<0.01,{ }^{* * *} \mathrm{p}<0.001$. 
(A)

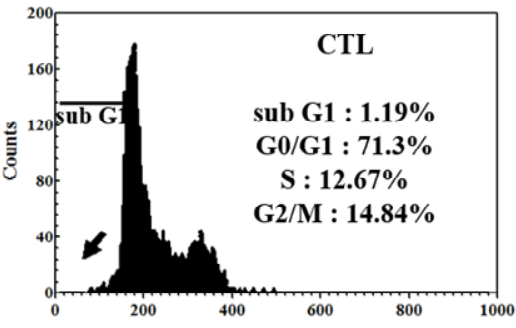

(D)

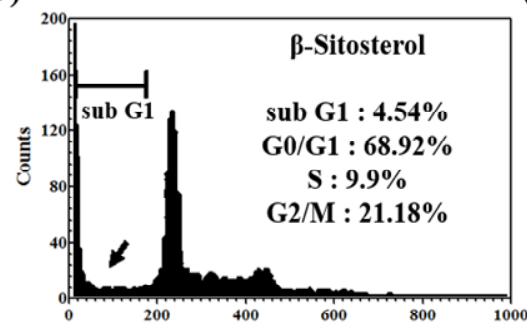

(B)

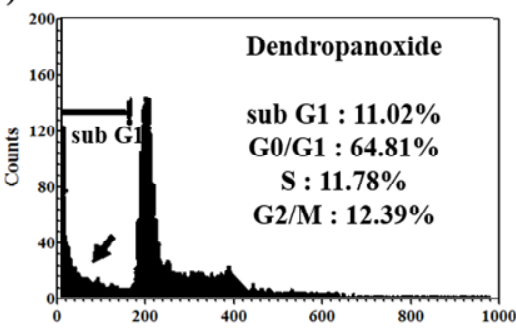

(E)

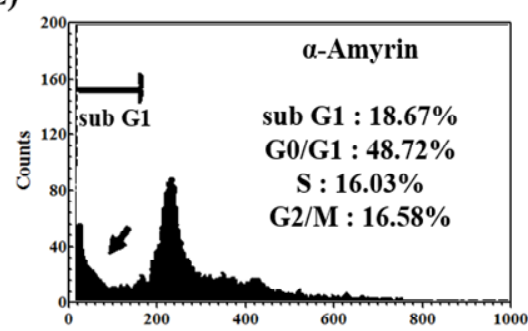

(C)

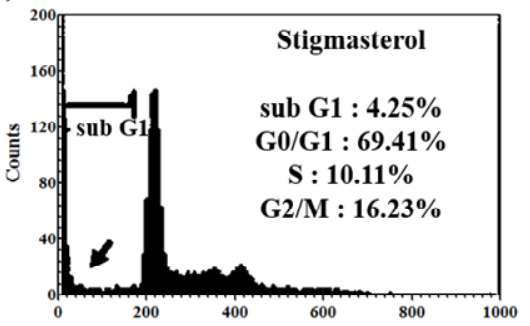

(F)

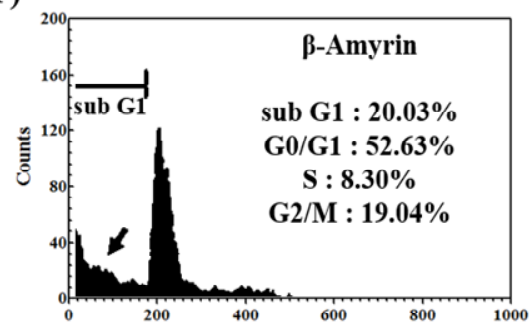

Fig. 7. DNA content frequency histograms and cell cycle distributions of MCF-7 cells treated with compounds for $24 \mathrm{~h}$.

Cells were collected and analyzed by flow cytometry. Apoptotic cells were calculated by measuring the area of a sub-G1 peak (arrows). Data are the mean of two different experiments.

(A)

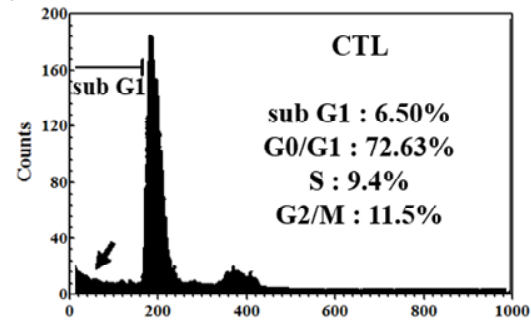

(D)

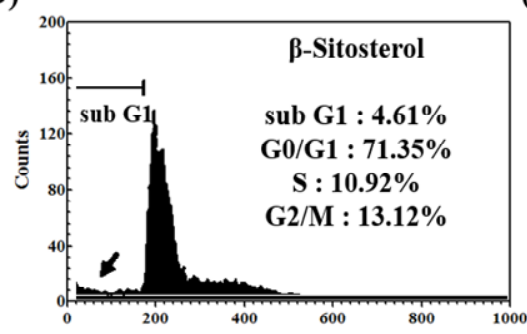

(B)

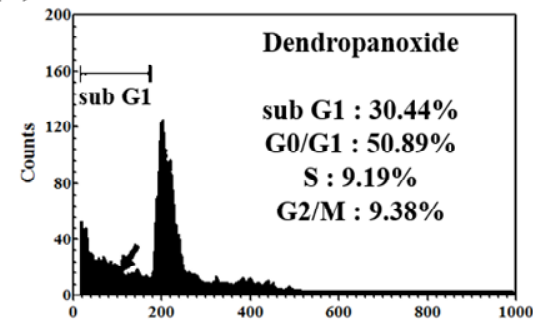

(E)

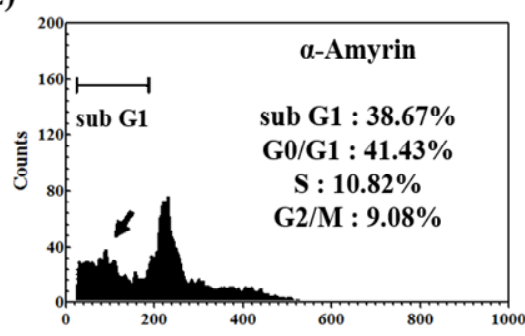

(C)

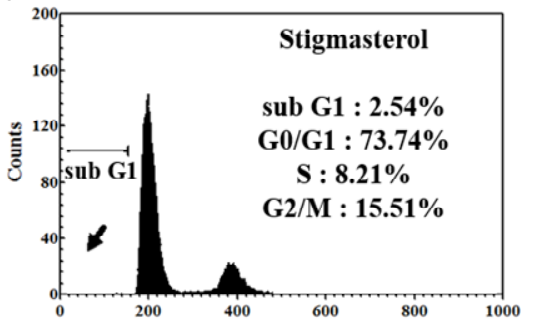

(F)

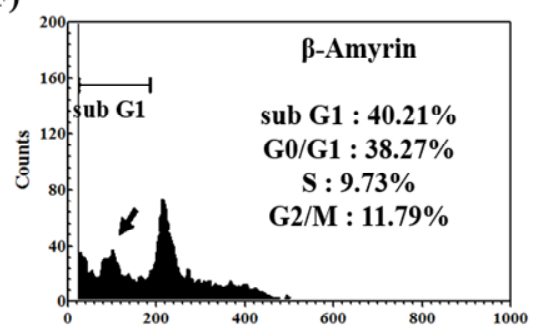

Fig. 8. DNA content frequency histograms and cell cycle distributions of A549 cells treated with compounds for $24 \mathrm{~h}$.

Cells were collected and analyzed by flow cytometry. Apoptotic cells were calculated by measuring the area of a sub-G1 peak (arrows). Data are the mean of two different experiments.

(stigmasterol, $\beta$-sitosterol, and dendropanoxide) failed to modify the level of Bax. The bcl-2 gene family is composed of a group related genes that either promote or prevent apoptosis $(38,39)$. The family members include anti-apoptotic genes, such as bcl-2 or bcl-xL, and pro-apoptotic ones such as Bax. The expression ratio of pro-apoptotic and anti-apoptotic genes may determine whether a cell lives or dies following an insult (40). Overexpression of Bcl-2 protein protects cells from apoptosis following exposure to a number of different pro-apoptotic stimuli $(41,42)$, whereas overexpression of Bax renders cells more sensitive to pro-apoptotic stimuli (43-45). Similarly, we also found that a-amyrin or $\beta$-amyrin treatment causes a decreased Bcl-2 expression and increased level of Bax, which may be responsible for the induction of apoptosis in MCF-7 and A549 cells. In our study, the levels of the anti-apoptotic Bcl-2 protein expression were decreased by compound 1 and compound 2, whereas protein expression of pro-apoptotic 
gene Bax was up regulated. Although we could not show that the induction of apoptosis was accompanied by the down-regulation of Bcl-2 expression and up-regulation of Bax expression on all compounds, suggesting that alteration of $\mathrm{Bcl}-2$ and $\mathrm{Bax}$ is directly or indirectly involved in the apoptotic effect of five compounds in MCF-7 and A549 cells. Thus, a-amyrin and $\beta$-amyrin may be a potential lead compound for further structural modification for anti-cancer drug development.

\section{Effects of compounds on cell cycle distribution} MCF-7 and A549 cells were exposed to $\mathrm{IC}_{50}$ concentrations of five compounds $(1,2,4,5$, and 6$)$ for $24 \mathrm{~h}$, and the cell cycle distribution was analyzed by flow cytometry (Fig. 7, Fig. 8). As shown in Fig. 7, in the absence of compounds (control, CTL), the cell populations at sub-G1, G0/G1, S, and $\mathrm{G} 2 / \mathrm{M}$ phases were found to be $1.19 \%, 71.3 \%, 12.67 \%$, and $14.84 \%$, respectively. Cells with sub-G1 DNA contents were scored as apoptosis based on the previous study (46). At $\mathrm{IC}_{50}$ concentration, five compounds $(1,2,4,5$, and 6) showed an increased cell population at sub-G1, an apoptotic phase, with $20.03 \%, 18.67 \%, 11.02 \%, 4.54 \%$, and $4.25 \%$, respectively, and concomitant decrease in the other phases of cell cycle. From the results it is confirmed that treatment of a-amyrin and $\beta$-amyrin induced MCF-7 cell apoptosis maximally. As demonstrated in Fig. 8, in the control cells, we could detect only a minor cell population $(6.5 \%)$ that underwent apoptosis in $\mathrm{A} 549$ cells. At $\mathrm{IC}_{50}$ concentration, five compounds $(1,2,4,5$, and 6) showed an increased cell population at sub-G1 with $40.21 \%, 38.67 \%, 30.44 \%, 4.61 \%$, and $2.54 \%$, respectively, and concomitant decrease in the other phases of cell cycle. These results support the suggestion that a-amyrin and $\beta$-amyrin actively arrested progression of the cell cycle and induces apoptosis in MCF-7 and A-549 cells.

\section{Summary}

Inhibition of cancer growth has been a continuous effort in cancer treatment. The in vitro cytotoxicity of the isolated compounds showed its significant anti-cancer activity against MCF-7 and A549 cells. In the present study, we have demonstrated for the first time that Olean-12-en-3,24 $\beta$-diol and stigmasterol, a new compound isolated from DP, although fail to induce apoptosis in human breast and lung cancer cells. Therefore, the study in the future is to be extended to other cancer cell lines and there is a need to carry out in vivo studied to further authenticate the anti-cancer potentials of these compounds. However, with a very low $\mathrm{IC}_{50}$ value, the isolated triterpenoids, especially at a-amyrin and $\beta$-amyrin, are again confirming their potential to become an alternative material to inhibit breast and lung cancer cells. The more precise signaling pathway by which isolated triterpenoids from DP triggers caspase-3 activation, cytochrome c release, and the other apoptotic phenomena described here remain to be identified. Nevertheless, we concluded that triterpenoids, derived from DP extract, demonstrated cytotoxic activity with a very low $\mathrm{IC}_{50}$ value. Thus, triterpenoids have potential to become an alternative medicinal to inhibit breast and lung cancer in the future.

\section{Acknowledgement}

The work was supported by the Korea Institute of Planning \& Evaluation for Technology in Food, Agriculture Forestry \& Fisheries (IPET) through the High Value-added Food Technology Development Program (316065-3).

\section{References}

1. Merghoub N, Benbacer L, Amzazi S, Morjani H, Elmzibri M (2009) Cytotoxic effect of some Moroccan medicinal plant extracts on human cervical cell lines. J Med Plants Res, 3, 1045-1050

2. Fridlender M, Kapulnik Y, Koltai H (2015) Plant derived substances with anti-cancer activity: from folklore to practice. Front Plant Sci, 6, 1-9

3. Khazaei S, Ramachandran V, Abdul Hamid R, Mohd Esa N, Etemad A, Moradipoor S, Ismail P (2017) Flower extract of Allium atroviolaceum triggered apoptosis, activated caspase-3 and down-regulated antiapoptotic Bcl-2 gene in HeLa cancer cell line. Biomed Pharmacother, 89, 1216-1226

4. Xu W, Liu J, Li C, Wu HZ, Liu YW (2008) Kaempferol-7-O- $\beta-D-$ glucoside $(\mathrm{KG})$ isolated from Smilax china L. rhizome induces G2/M phase arrest and apoptosis on HeLa cells in a p53-independent manner. Cancer Lett, 264, 229-240

5. Dwivedi V, Shrivastava R, Hussain S, Ganguly C, Bharadwaj M (2011) Cytotoxic potential of Indian spices (extracts) against esophageal squamous carcinoma cells. 
Asian Pac J Cancer Prev, 12, 2069-2073

6. Kaufmann SH (1989) Induction of endonucleolytic DNA cleavage in human acute myelogenous leukemia cells by etoposide, camptothecin, and other cytotoxic anticancer drugs: A cautionary note. Cancer Res, 49, 5870-5878

7. Hickman JA (1992) Apoptosis induced by anticancer drugs. Cancer Metastasis Rev, 11, 121-139

8. Smets LA (1994) Programmed cell death (apoptosis) and response to anti-cancer drugs. Anticancer Drugs, 5, 3-9

9. Chen Z, Naito M, Mashima T, Tsuruo T (1996) Activation of actin-cleavable interleukin 1 1 -converting enzyme (ICE) family protease CPP-32 during chemotherapeutic agent-induced apoptosis in ovarian carcinoma cells. Cancer Res, 56, 5224-5229

10. White E (1996) Life, death, and the pursuit of apoptosis. Genes Dev, 10, 1-15

11. Rao L, White E (1997) Bcl-2 and ICE family of apoptotic regulators: making a connection. Curr Opin Genet Dev, 7, $52-58$

12. Takahashi A, Earnshaw WC (1996) ICE-related proteases in apoptosis. Curr Opin Genet Dev, 6, 50-55

13. Gajewski TF, Thompson CB (1996) Apoptosis meets signal transduction: Elimination of a BAD influence. Cell, 87, 589-592

14. Chinnaiyan AM, Orth K, O'Rourke K, Duan H, Poirier GG, Dixit VM (1996) Molecular ordering of the cell death pathway: Bcl-2 and Bcl-xL function upstream of the CED-3-like apoptotic proteases. J Biol Chem, 271, 4573-4576

15. Shimizu S, Eguchi Y, Kamiike W, Matsuda H, Tsujimoto Y (1996) Bcl-2 expression prevents activation of the ICE protease cascade. Oncogene, 12, 2251-2257

16. Lee JW, Park C, Han MH, Hong SH, Lee TK, Lee SH, Kim GY, Choi YH (2013) Induction of human leukemia U937 cell apoptosis by an ethanol extract of Dendropanax morbifera Lev. through the caspase-dependent pathway. Oncol Rep, 30, 1231-1238

17. Lee SH, Lee HS, Park YS, Hwang B, Kim JH, Lee HY (2002) Screening of immune activation activities in the leaves of Dendropanax morbifera Lev. Korean J Medicinal Crop Sci, 10, 109-115

18. Lee JW, Kim KS, An HK, Kim CH, Moon HI, Lee YC (2013) Dendropanoxide induces autophagy through ERK1/2 activation in MG-63 human osteosarcoma cells and autophagy inhibition enhances dendropanoxide-induced apoptosis. PLoS One, 8, e83611

19. Jin CY, Yu HY, Park C, Han MH, Hong SH, Kim KS,
Lee YC, Chang YC, Cheong J, Moon SK, Kim GY, Moon HI, Kim WJ, Lee JH, Choi YH (2013) Oleifolioside B-mediated autophagy promotes apoptosis in A549 human non-small cell lung cancer cells. Int J Oncol, 43, 1943-1950

20. Yu HY, Jin CY, Kim KS, Lee YC, Park SH, Kim GY, Kim WJ, Moon HI, Choi YH, Lee JH (2012) Oleifolioside A mediates caspase-independent human cervical carcinoma $\mathrm{HeLa}$ cell apoptosis involving nuclear relocation of mitochondrial apoptogenic factors AIF and EndoG. J Agric Food Chem, 60, 5400-5406

21. Im KJ, Jang SB, Yoo DY (2015) Anti-cancer Effects of Dendropanax morbifera extract in MCF-7 and MDA-MB-231 cells. J Korean Obstet Gynecol, 28, 26-39

22. Choi JH, Kim DW, Park SE, Lee HJ, Kim KM, Kim KJ, Kim MK, Kim SJ, Kim S (2015) Anti-thrombotic effect of rutin isolated from Dendropanax morbifera Leveille. J Biosci Bioeng, 120, 181-186

23. Park SE, Sapkota K, Choi JH, Kim MK, Kim YH, Kim KM, Kim KJ, Oh HN, Kim SJ, Kim S (2014) Rutin from Dendropanax morbifera Leveille protects human dopaminergic cells against rotenone induced cell injury through inhibiting JNK and p38 MAPK signaling. Neurochem Res, 39, 707-718

24. Park BY, Min BS, Oh SR, Kim JH, Kim TJ, Kim DH, Bae KH, Lee HK (2004) Isolation and anticomplement activity of compounds from Dendropanax morbifera. J Ethnopharmacol, 90, 403-408

25. Setzer WN, Green TJ, Whitaker KW, Moriarity DM, Yancey CA, Lawton RO, Bates RB (1995) A cytotoxic diacetylene from Dendropanax arboreus. Planta Med, 61, 470-471

26. Bernart MW, Cardellina JH, Balaschak MS, Alexander MR, Shoemaker RH, Boyd MR (1996) Cytotoxic falcarinol oxylipins from Dendropanax arboreus. J Nat Prod, 59, 748-753

27. Chung IM, Kim MY, Park WH, Moon HI (2009) Antiatherogenic activity of Dendropanax morbifera essential oil in rats. Pharmazie, 64, 547-549

28. Chung IM, Song HK, Kim SJ, Moon HI (2011) Anticomplement activity of polyacetylenes from leaves of Dendropanax morbifera Leveille. Phytother Res, 25, 784-786

29. Lee SY, Choi EJ, Bae DH, Lee DW, Kim S (2015) Effects of 1-tetradecanol and $\beta$-sitosterol isolated from Dendropanax morbifera Lev. on skin whitening, moisturizing and preventing hair loss. J Soc Cosmet Sci 
Korea, 41, 73-83

30. Kim G, Kim JE, Kang MJ, Jang AR, Kim YR, Kim S, Chang KT, Hong JJ, Park JH (2017) Inhibitory effect of 1 tetradecanol on Helicobacter pylori-induced production of interleukin 8 and vascular endothelial growth factor in gastric epithelial cells. Mol Med Rep, 16, 9573-9578

31. Park JU, Kang BY, Lee HJ, Kim S, Bae D, Park JH, Kim YR (2017) Tetradecanol reduces EL-4 T cell growth by the down regulation of NF- $\mathrm{kB}$ mediated $\mathrm{IL}-2$ secretion. Eur J Pharmacol, 799, 135-142

32. Maiyo F, Moodley R, Singh M (2016) Phytochemistry, cytotoxicity and apoptosis studies of $\beta$-sitosterol-3-oglucoside and $\beta$-amyrin from Prunus aericana. Afr J Tradit Complementary Altern Med, 13, 105-112

33. Ali H, Dixit S, Ali D, Alqahtani SM, Alkahtani S, Alarifi $S$ (2015) Isolation and evaluation of anticancer efficacy of stigmasterol in a mouse model of DMBA-induced skin carcinoma. Drug Des Dev Ther, 9, 2793-2800

34. Denizot F, Lang R (1986) Rapid colorimetric assay for cell growth and survival modification to the tetrazolium dye procedure giving improved sensitivity and reliability. J Immuno Methods, 89, 271-277

35. Senthilraja P, Kathiresan $K$ (2015) In vitro cytotoxicity MTT assay in Vero, HepG2, and MCF-7 cell lines study of marine yeast. J Appl Pharm Sci, 5, 80-84

36. Fisher TC, Milner AE, Gregory CD, Jackman AL, Aherne GW, Hartley JA, Dive C, Hickman JA (1993) Bcl-2 modulation of apoptosis induced by anticancer drugs: resistance to thymidylate stress is independent of classical resistance pathways. Cancer Res, 53, 3321-3326

37. Chen QY, Wu LJ, Wu YQ, Lu GH, Jiang ZY, Zhan JW, Jie Y, Zhou JY (2009) Molecular mechanism of trifluoperazine induces apoptosis in human A549 lung adenocarcinoma cell lines. Mol Med Rep, 2, 811-817

38. Boise LH, Gonzalez-Garcia M, Postema CE, Ding L,
Lindsten T, Turka LA, Mao X, Nunez G, Thompson CB (1993) Bcl-x, a Bcl-2 related gene that functions as a dominant regulator of apoptotic cell death. Cell, 74, 597-608

39. Oltvai ZN, Milliman CL, Korsmeyer SJ (1993) Bcl-2 heterodimerizes in vivo with a conserved homolog, Bax, that accelerates programmed cell death. Cell, 74, 609-619

40. Oltvai ZN, Korsmeyer SJ (1994) Checkpoints of dueling dimers foil death wishes. Cell, 79, 189-192

41. Chiou SK, Rao L, White E (1994) Bcl-2 blocks p53-dependent apoptosis. Mol Cell Biol 14, 2556-2563

42. Dole M, Nunez G, Merchant AK, Maybaum J, Rode CK, Bloch CA, Castle VP (1994) Bcl-2 inhibits chemotherapy-induced apoptosis in neuroblastoma. Cancer Res, 54, 3253-3259

43. Bargou RC, Wagener C, Bommert K, Mapara MY, Daniel PT, Arnold W, Dietel M, Guski H, Feller A, Royer HD, Dorken B (1996) Overexpression of the death-promoting gene bax- $a$ which is down regulated in breast cancer restores sensitivity to different apoptotic stimuli and reduces tumor growth in SCID mice. J Clin Invest, 97, 2651-2659

44. Strobel T, Swanson L, Korsmeyer S, Cannistra SA (1996) BAX enhances paclitaxel- induced apoptosis through a p53-independent pathway. Proc Natl Acad Sci USA, 93, 14094-14099

45. Wagener C, Bargou RC, Daniel PT, Bommert K, Mapara MY, Royer HD, Dorken B (1996) Induction of the death-promoting gene bax- $a$ sensitizes cultured breast-cancer cells to drug-induced apoptosis. Int $\mathbf{J}$ Cancer, 67, 138-241

46. Nicoletti I, Migliorati G, Pagliacci MC, Grignani F, Riccardi C (1991) A rapid and simple method for measuring thymocyte apoptosis by propidium iodide staining and flow cytometry. J Immunol Methods, 139, 271-279 